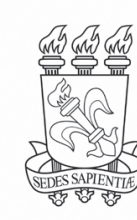

\title{
Artigos
}

\section{Role of soil fauna to litter decomposition in pine stands under Atlantic Forest biome}

\author{
Papel da fauna do solo na decomposição da serapilheira em \\ povoamentos de pinus sob bioma Mata Atlântica
}

\author{
Tatiani Maria Pech' ${ }^{\oplus}$ \\ Guilherme Diego Fockink ${ }^{10}$ \\ Alexandre Siminski' ${ }^{\oplus}$ \\ Júlia Carina Niemeyer ${ }^{\bullet}$
}

'Universidade Federal de Santa Catarina, Curitibanos, SC, Brazil

\begin{abstract}
Litter production and its decomposition play an important role in the terrestrial carbon cycle and soil quality, being a crucial process involved in ecosystem productivity and functioning. Understanding this process under pine commercial stands or pine invasions is crucial to design forest management or ecosystems restoration. We conducted a study in a commercial pine plantation (Pinus taeda L.) under Atlantic Forest biome to investigate (1) the contribution of soil fauna to pine litter mass loss; (2) the litter fauna feeding activity within seasons. Litter bags with pine needles ( $5 \mathrm{~g}$ dry weight) were prepared as exclusion treatments for different sized soil fauna by varying mesh size ( $2 \mathrm{~mm}$ and $0.06 \mathrm{~mm}$ ). Litter bags were removed after $60,120,180,240,300$, and 365 days to estimate the decomposition rates. Bait lamina sticks were exposed seasonally and horizontally in soil surface to determine the fauna feeding activity on litter. We found: (1) no differences in litter mass loss and decomposition rate when soil macrofauna and most of the mesofauna were excluded; (2) feeding activity of litter organisms was higher in the summer, probably stimulated by a combination of high temperature and rainfall. In commercial pine stands, we can conclude that the nutrient cycling is slower than in natural areas, related to litter traits, as described in the scientific literature. Our results indicated that soil macro and mesofauna play a low role in the pine litter decomposition, where the organic material decomposition is more related to microorganism's activity.
\end{abstract}

Keywords: Bait lamina; Forest ecology; Litter bags; Soil invertebrates 


\section{RESUMO}

A produção de serapilheira e sua decomposição desempenham um papel importante no ciclo do carbono terrestre e na qualidade do solo, sendo um processo crucial envolvido na produtividade e funcionamento do ecossistema. Compreender esse processo em áreas comerciais de pinus ou invasões de pinus é crucial para projetar o manejo florestal ou a restauração de ecossistemas. Conduzimos um estudo em uma plantação comercial de pinus (Pinus taeda L.) no bioma da Mata Atlântica para investigar (1) a contribuição da fauna do solo para a perda de massa da serapilheira; (2) a atividade alimentar da fauna edáfica na serapilheira dentro das estações do ano. As bolsas de decomposição com acículas de pinus ( $5 \mathrm{~g}$, peso seco) foram preparadas como tratamentos de exclusão para a fauna do solo de diferentes tamanhos, variando o tamanho da malha ( $2 \mathrm{~mm}$ e 0,06 mm). As bolsas de decomposição foram removidas após 60, 120, 180, 240, 300 e 365 dias para estimar as taxas de decomposição. Bait laminas foram expostos sazonalmente e horizontalmente na superfície do solo para determinar a atividade de alimentação da fauna na serapilheira. Encontramos: (1) nenhuma diferença na perda de massa da serapilheira e na taxa de decomposição quando a macrofauna do solo e a maior parte da mesofauna foram excluídas; (2) a atividade alimentar dos organismos da serapilheira foi maior no verão, provavelmente estimulada por uma combinação de alta temperatura e umidade. Em plantios comerciais de pinus, podemos concluir que a ciclagem de nutrientes é mais lenta do que em áreas naturais, o que está relacionado às características das acículas, descritas na literatura. Nossos resultados indicaram que a macro e a mesofauna do solo desempenham um papel menor na decomposição da serapilheira em plantios comerciais de pinus, indicando que o processo de decomposição em tais povoamentos está mais relacionada à atividade dos microrganismos.

Palavras-chave: Bait lamina; Ecologia florestal; Bolsa de decomposição; Invertebrados do solo

\section{INTRODUCTION}

Species of Pinus are commonly planted for forestry purposes and have strong economic impacts on the local and national economies of many countries worldwide (CUBBAGE et al., 2020). However, their impact on global biodiversity is also under concern, as wood production has increased and exotic species are currently considered as a choice to achieve high production levels (DODET; COLLET, 2012). Understanding ecosystem functioning in such systems is needed to improve economic and environmental aspects, as well as to establish recovering strategies for invasive areas.

Litter decomposition plays an important role in the terrestrial carbon cycle and soil quality. In forest ecosystems, litter production and its breakdown are part of the nutrient cycling, being a crucial process for the ecosystem productivity (HUANG; ZHAO; 
$\mathrm{LI}, 2017)$. The environmental conditions and vegetation type are important factors in determining the quality and the amount of material that reaches the soil (MCCAY; CARDELÚS; NEATROUR, 2013). Studies have been performed to investigate the litter decomposition of pine species (HE et al., 2020), discussing climatic conditions and litter characteristics that influence this process. However, there is no sufficient information about the role of macro and mesofauna groups in pine litter breakdown. Preview studies have shown the effects of Pinus species to understory plant species (FOCKINK et al., 2020) and soil invertebrates' community (ORTIZ et al., 2021) in pine plantation and invasions, which point impacts for ecosystems where Pinus spp. are non-native.

In productive systems, litter decomposition is the main route for the transfer of the vegetation nutrients to the soil, besides protecting the soil from erosion, supplying organic material and nutrient to soil fauna and plants, maintaining and improving the physical, chemical and biological properties of the soil (LIU et al., 2017). The soil-litter macro and mesofauna have a crucial role in ecosystem functioning and soil quality, by their feeding and dig, acting on the fragmentation of plant residues, improving soil physical structure and chemical quality, and establishing relationships at different levels with microorganisms (improving and controlling microorganism's populations) (COYLE et al., 2017). Although several studies embraced pine litter decomposition, further research is needed to establish more quantitative relationships among soil fauna and its role in nutrient cycling (NEHER; WEICHT; BARBERCHECK, 2012).

In this context, this study was designed to answer the following questions: (1) What is the contribution of soil macro and mesofauna to pine litter decomposition at commercial stands inside the Atlantic Forest biome? (2) What is the P. taeda L. litter decomposition rate in a plateau region in southern Brazil? (3) Does the soil fauna feeding activity differ among seasons in these systems and region? We hypothesized that, as pine litter has both physical and chemical properties that impair several soil invertebrates groups, and such material presents slow decomposition rates in all biomes, the exclusion of soil macro and mesofauna would be of low importance to 
litter decomposition, which could indicate that this process is specially carried out by microorganisms. To test this hypothesis, we conducted a field experiment to investigate the comparative pine litter decomposition rates in litter bags with a mesh size that allowed and excluded the entrance of macro and mesofauna.

\section{MATERIAL AND METHODS}

\subsection{Site description}

The experiment was located in the vicinity of the Federal University of Santa Catarina (UFSC) at the municipality of Curitibanos, in the plateau region $(987 \mathrm{~m}$ altitude) of Santa Catarina State, Brazil. The climate according to Köppen-Geiger is temperate (Cfb), humid mesothermal, and mild summer, showing an average annual temperature between $16^{\circ} \mathrm{C}$ and $17^{\circ} \mathrm{C}$. The biome of the region is Atlantic Forest, composed of Mixed Ombrophilous Forest (Araucaria Forest). According to Barbosa et al. (2017), the predominant soil type is characterized as very clayed Aluminic Humic Cambisol. The study was conducted in a commercial pinus plantation of the species Pinus taeda L. (loblolly pine), owned by Agropastoril Gaboardi Ltda company. This plantation was established in 2005 (13 years old when our experiment was carried out) with an initial spacing of $2.5 \times 2.5 \mathrm{~m}$ among trees, for timber production to the sawmill. Selective pruning was carried out in 2013 and 2017, but in this last period, the plots with the experiments were excluded. There was no use of chemicals in this area. The air temperature and rainfall data during the experiment were provided by the Meteorological Station of CIRAM/EPAGRI.

\subsection{Evaluation of the litter decomposition by the litter bags method}

Three plots of $10 \mathrm{~m} \times 30 \mathrm{~m}$ were delineated (300 $\mathrm{m}^{2}$ per plot), $10 \mathrm{~m}$ distant from each order, and $20 \mathrm{~m}$ from the edge. Recently pine needles which had fallen in collectors $(1.0 \times 1.0 \mathrm{~m})$ were transported to the laboratory, where they were dried in 
air circulation and renewal oven at $60^{\circ} \mathrm{C}$, until reaching a constant weight ( 7 days). Dry needles (5 g) were weighed in nylon bags (litter bags), with meshes of $0.06 \mathrm{~mm}$ and $2 \mathrm{~mm}$, here named as fine and coarse mesh bags, respectively, with dimensions of $15 \mathrm{~cm} \times 15 \mathrm{~cm}$. The objective was to have bags that excluded the entrance of the edaphic macro and mesofauna (fine mesh) and bags that allowed the entrance of these organisms (coarse mesh), which allowed to monitor the decomposition with and without the presence of fauna. The bags in each plot were arranged in rows $0.50 \mathrm{~m}$ distant among them, and $0.30 \mathrm{~m}$ distant among bags.

The mechanical loss of needles until the arrival in the study area was estimated in ten bags, which returned to the lab for a new weighting on the same day. These values were used as a correction in the decomposition rate calculation, deducting this mechanical loss.

Decomposition bags were exposed for 365 days and removed after 60, 120, 180, 240,300 , and 365 days of exposure. In each removal time, five bags of each mesh were collected (randomly) per plot to estimate the decomposition rates. The reminiscent litter mass (\%) was calculated by the expression MR\% = $(\mathrm{Mf} / \mathrm{Mi}) \times 100$. Where: $\mathrm{MR} \%=$ dry weight percentage of remaining litter mass; $\mathrm{Mf}=$ dry weight of final litter mass; Mi $=$ initial dry weight of litter mass.

After the remaining mass calculation throughout the period, the $\mathrm{k}$ decomposition constant was calculated, according to Thomas and Asakawa (1993), with the exponential model: $X_{t}=X_{o}$. $e^{-k t}$. Where: $X_{t}=$ remaining dry material weight after $t$ days; $X_{o}=$ weight of the dry material placed in bags at zero time $(t=0)$. To calculate the $k$ decomposition constant, the total period of exposure (365 days) was taken into account, therefore, data from the last sampling were used for this purpose.

The half-life time $\left(t_{1 / 2}\right)$ was calculated according to Rezende et al. (1999), which expresses the time required for half of the residues decomposing or for half of the 
nutrients contained in these residues being released, the time equivalent to the decomposition of $95 \%$ of the residue was also estimated, considering the Equation (1) and (2):

$$
\begin{aligned}
& \mathrm{T}_{1 / 2}=\ln (2) / \mathrm{K} \\
& \mathrm{T}_{95 \%}=3 / \mathrm{K}
\end{aligned}
$$

In where: $\mathrm{Ln}(2)$ and 3 is a constant value and $\mathrm{K}=$ constant of decomposition calculated by the previous formula $\left(X_{t}=X_{0} \cdot e^{-k t}\right)$.

\subsection{Feeding activity of soil fauna by the bait lamina method}

The bait lamina method standardized by ISO 18311 (ISO, 2016) was used to evaluate the feeding activity of the litter organisms. This method consists of plastic laminas with $120 \mathrm{~mm}$ in length and $1 \mathrm{~mm}$ in thickness, containing 16 holes, each with $2 \mathrm{~mm}$ of diameter and with a distance between them of $5 \mathrm{~mm}$. The lamina holes were manually filled with an organic mixture containing $70 \%$ of cellulose, $27 \%$ of wheat flour, and $3 \%$ of active carbon. The litter fauna feeding activity was evaluated with the bait lamina method in the four seasons of the year; however, we chose to use the laminas horizontally (Figure 1), i.e. on the litter and not as commonly used, buried in the ground. The bait material does not necessarily mimic the complexity of the natural litter material, but they provide a standard method of comparison across seasons.

A total of 96 bait laminas was used for each season of the year, which were distributed among the plots. Each plot received 32 bait laminas, distributed in three groups of 8 bait laminas each. Horizontal bait laminas were attached to the surface with a wire in the shape of a reversed " $U$ ". The laminas were exposed in the field for 30 days. The laminas were carefully removed and visually examined against the light, counting and recording the holes with more than $30 \%$ of consumption. 
Figure 1 - Bait lamina sticks arranged horizontally on the pine litter layer in pine stand

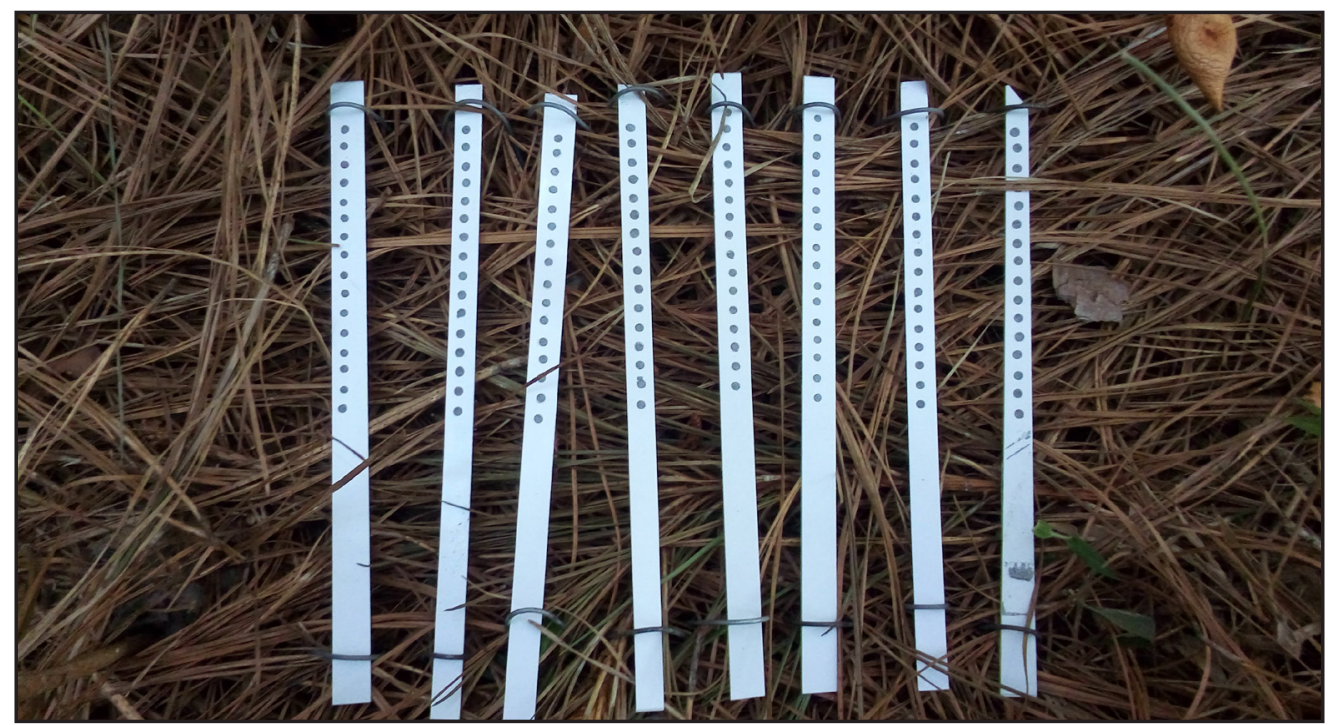

Source: Authors (2018)

\subsection{Data analysis}

Normality and homoscedasticity of litter bags and bait lamina data were checked by Shapiro-Wilk e Bartlett tests. The litter decomposition data (remaining \% for each mesh size and exposure period) were subjected to Variance Analysis (ANOVA) twoway, following a randomized block design in a factorial scheme (treatment $x$ time), by the statistical software R (R CORE TEAM, 2018). The Tukey test $(p<0.05)$ was adopted for comparing the averages, and the Pearson Correlation Coefficient to determine the linear correlation coefficient between the litter mass loss and two qualitative variables (temperature and rainfall). The consumption percentage of the bait lamina was compared among the seasons using the non-parametric Kruskal-Wallis test $(p<0.05)$.

\section{RESULTS AND DISCUSSION}

\subsection{Climatic conditions}

The climatic conditions during the litter bags and bait lamina exposure were according to the expected for the period. The total rainfall was $1378.2 \mathrm{~mm}$, with 
maximum values in October 2017 (194 mm) and January 2018 (245 mm), and the lowest in July (15.2 mm) and September 2017 (40.8 mm). The highest average temperature occurred in December $2017\left(20.3^{\circ} \mathrm{C}\right)$ and the lowest in July $2017\left(11.7^{\circ} \mathrm{C}\right)$ (Figure 2).

Figure 2 - Average monthly values of temperature and precipitation in the study area. Data from Meteorological Station of CIRAM, EPAGRI, SC, Brazil

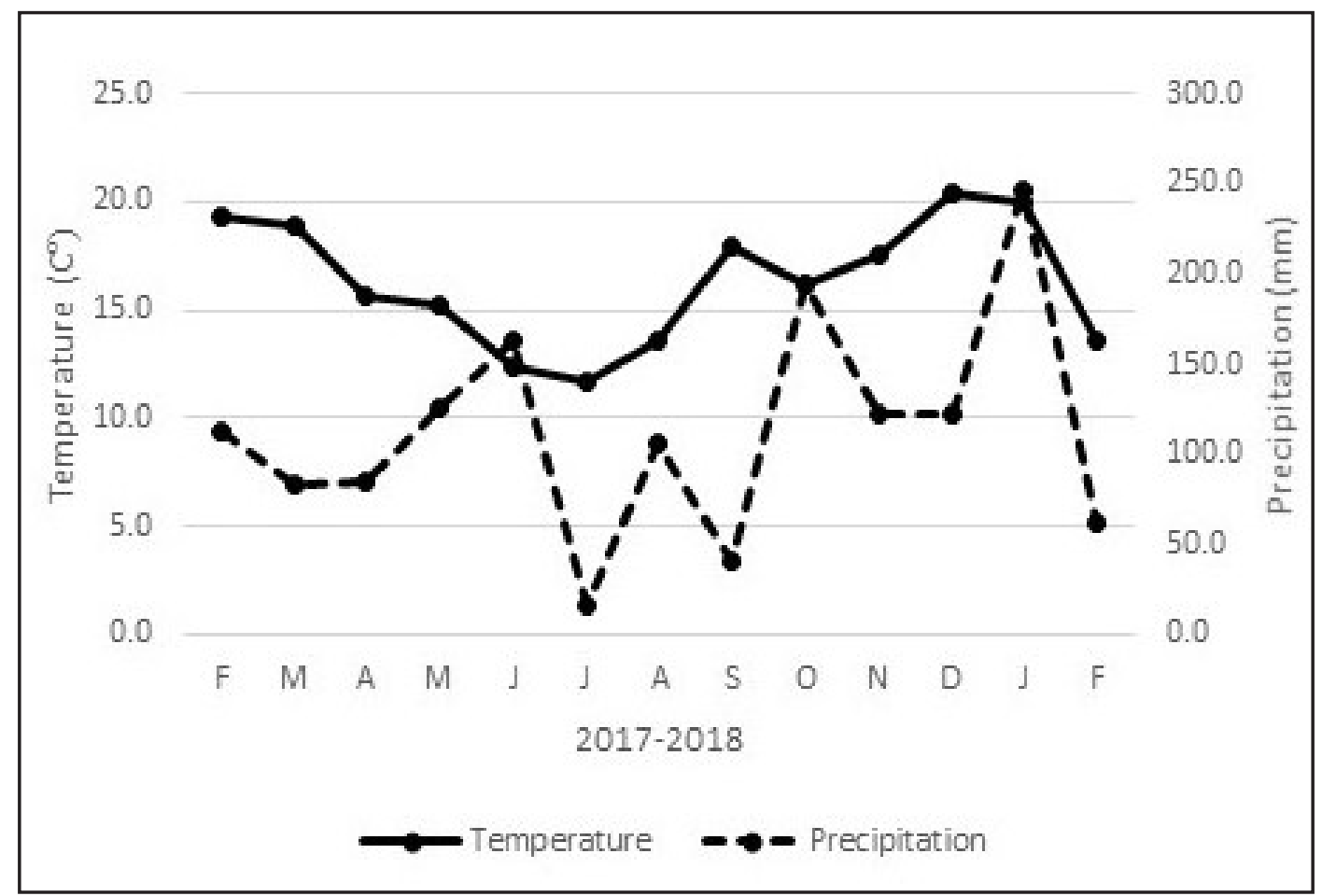

Source: Authors (2018)

\subsection{Litter decomposition}

The litter mass loss is shown in Figure 3. No statistically significant difference was found by the Tukey test $(p<0.05)$ between mesh sizes; however, statistical differences were observed in the sampled times, within each mesh size, i.e. including or excluding the edaphic macro and mesofauna (Table 1). After 365 days, the total litter mass loss corresponded to $43.2 \%$ in mesh $2 \mathrm{~mm}$ and $45.4 \%$ in mesh $0.06 \mathrm{~mm}$, not differing significantly among them. 
Table 1 - Reminiscent litter mass in litter bags excluding (fine mesh, $0.06 \mathrm{~mm}$ ) or not (coarse mesh, $2.00 \mathrm{~mm}$ ) soil macro and mesofauna, exposed in a pine plantation, compared by two-way ANOVA (mesh $x$ time), followed by Tukey test $(p<0.05)$

\begin{tabular}{lcccccc}
\hline \multirow{2}{*}{ Litter bags mesh size } & \multicolumn{7}{c}{ Time (days) } \\
\cline { 2 - 7 } & $\mathbf{6 0} \dagger$ & $\mathbf{1 2 0}$ & $\mathbf{1 8 0}$ & $\mathbf{2 4 0}$ & $\mathbf{3 0 0}$ & $\mathbf{3 6 5}$ \\
\hline $0.06 \mathrm{~mm} \neq$ & $83.0 \mathrm{Aa}$ & $72.6 \mathrm{Ba}$ & $68.2 \mathrm{Ba}$ & $64.5 \mathrm{Aba}$ & $63.9 \mathrm{Aba}$ & $54.6 \mathrm{Ca}$ \\
$2.00 \mathrm{~mm}$ & $84.6 \mathrm{Aa}$ & $73.7 \mathrm{Ba}$ & $72.2 \mathrm{Ba}$ & $68.4 \mathrm{Aba}$ & $64.2 \mathrm{Aba}$ & $56.8 \mathrm{Ca}$ \\
\hline
\end{tabular}

Source: Authors (2018)

In where: Averages followed by the same lowercase letters in the column not differ, by the Tukey Test ( $p<0.05)$; Averages followed by the same uppercase letters in the lines do not differ by the Tukey Test $(p<0.05)$.

Regarding the decomposition dynamics, the mass loss was higher in the first 120 days, for both mesh sizes (Figure 3). When studying the correlation between rainfall and temperature with litter mass loss, no significant correlations were observed by Pearson Correlation Coefficient analysis: for rainfall and the coarse mesh bags, $p=0.78$ and $\mathrm{R}=0.14$; rainfall and fine mesh bag, $p=0.59$ and $\mathrm{R}=0.27$; temperature and coarse mesh, $p=0.92$ and $\mathrm{R}=0.05$; temperature and fine mesh, $p=0.69$ and $\mathrm{R}=0.20$.

Figure 3 - Reminiscent litter mass (\%) in litter bags excluding (fine mesh, $0.06 \mathrm{~mm}$ ) or not (coarse mesh, $2 \mathrm{~mm}$ ) soil fauna, exposed on the litter layer of a Pinus taeda stand

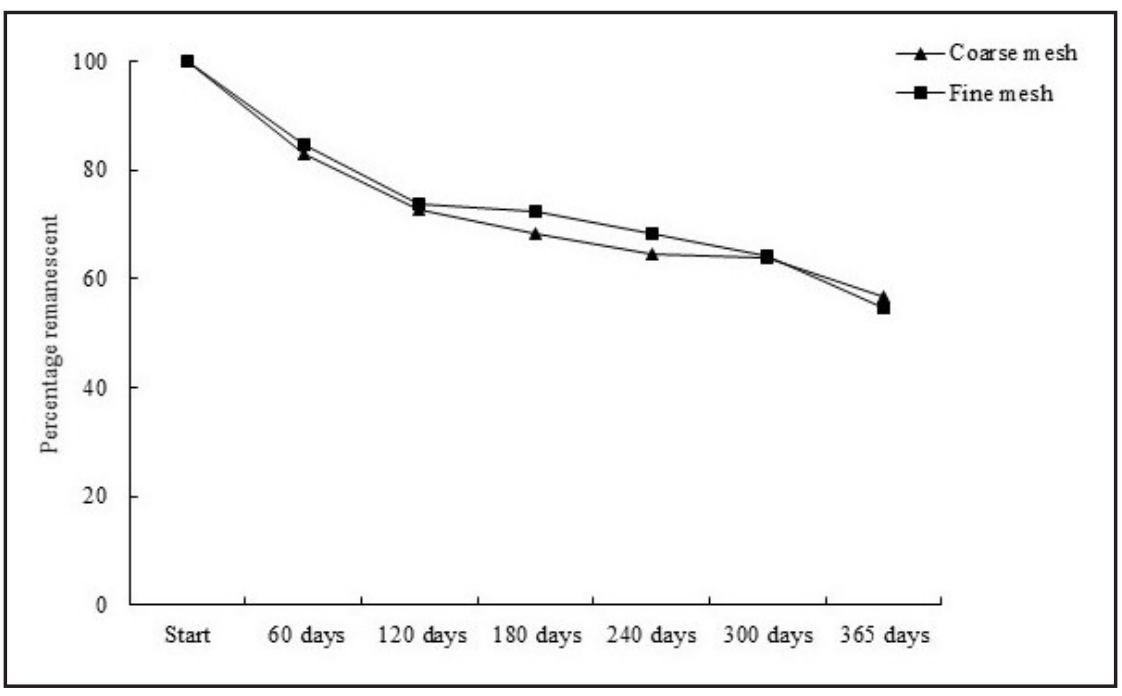

Source: Authors (2018) 
The estimated time to decompose $50 \%$ and $95 \%$ of the total litter mass is presented in Table 2. According to this calculation, the average time of litter renewal would be higher than 1 year for both treatments.

Table 2 - Decomposition constant (K) and the time (days) required for decomposition of 50\% ( $\left.\mathrm{T}_{1 / 2}\right)$ and 95\% (T 95\%) of $P$. taeda litter mass, excluding (mesh $0.06 \mathrm{~mm}$ ) or not (mesh $2.00 \mathrm{~mm}$ ) the main soil macro and mesofauna groups

\begin{tabular}{cccc}
\hline Litter bags mesh & kg g $^{-1}$ day $^{-1}$ & $\mathrm{~T}_{1 / 2}$ (days) & T 95\% (days) \\
\hline $0.06 \mathrm{~mm}$ & 0.0017 & 418 & 1810 \\
$2.00 \mathrm{~mm}$ & 0.0015 & 448 & 1937 \\
\hline
\end{tabular}

Source: Authors (2018)

The presence of large fauna has a recognized impact on decomposition in terrestrial ecosystems around the world (a review in HANDA et al., 2014). While soil fauna has an important role to organic material decomposition in the rainforest, influencing $\mathrm{N}$ and $\mathrm{C}$ cycles (e.g., YANG; CHEN, 2009), and it is the main driver on Pinus massoniana litter decomposition and breakdown of its refractory compounds (ZHANG et al., 2019), our field experiment using litter bags showed no significant differences in litter mass loss when macrofauna and most of the mesofauna were excluded. Our results showed that soil macro and mesofauna play a low role in the pine litter decomposition, indicating that the organic material decomposition in pine stands is more related to microorganism's activity. Besides microflora (e.g., bacteria, fungi), the role of microfauna cannot be excluded, as these small organisms could enter in the fine mesh bags. Neher, Weicht and Barbercheck (2012) showed that litter decomposition and $\mathrm{N}$ availability in pine forest soils were correlated with microarthropods and nematodes communities. In the present study, we assumed that decomposition in fine mesh litter bags could involve both microflora and microfauna groups.

The role of litter fauna on litter mass loss is dependent on litter composition (AUGUSTO et al., 2014). Low-quality litter can show significantly lower fauna effects 
in the decomposition process ( $\mathrm{LI}$ et al., 2015a). Pine species including $P$. taeda are recognized as low quality showing slow decomposition rates, which depends on climatic conditions and its effects on microbial growth rate (OLSSON et al., 2019). Higher decay in litter reminiscent material at the beginning of the process can be related to the decomposition of water-soluble compounds and some labile organic components, while the lower decay in late stages is related to recalcitrant components (ZHANG et al., 2019). Needles of coniferous species contain more recalcitrant compounds such as cellulose, hemicelluloses, lignin, and tannins when compared with broad-leaved tree species (GUO et al., 2009), besides needles being a hard material to be breakdown by soil faunal groups, which justify the main role of microorganisms, especially fungi (PURAHONG et al., 2014), in this process.

The litter moisture, provided by microclimate, can be an important factor in the decomposition process. Litter from the fine mesh litter bags presented visually higher moisture (with small drops of water) than that from the coarse mesh. Furthermore, the presence of fungal mycelia was pronounced inside the fine mesh bags. Similar characteristics like fungi mycelia were also observed by Gama-Rodrigues, Barros and Santos (2003) when studying the decomposition of species of the Eucalyptus genus. As the fine bags probably decrease the moisture loss, it could favor microorganism's activity and therefore affect the decomposition rates, according to local climatic conditions. On the other hand, the coarse mesh could favor the leaching and loss of mass. The authors concluded that different mesh sizes can be used to reliably quantify the role of soil macro and mesofauna in litter mass loss from litter bags and that the loss of material in the coarse mesh is related to these organisms by promoting litter decomposition as well as due to greater litter fragmentation, losing undecomposed fragments from the bags.

Decomposition constant and the time to decompose 50 and $95 \%$ of $P$. taeda litter indicated a slow process for this species at the study site. Litter mass loss and its chemical composition are dependent on both plant species and climate conditions 
(LI et al., 2015b). Several author discussed that increasing temperature can improve the pine litter decomposition (SALAH; SCHOLES, 2011), enhancing biological activity and degradation of chemical compounds such as hemicellulose (COÛTEAUX; ALOUI; BESSON, 2002).

Management of the forest stands can also influence the colonization of the litter layer in stands (MORRISON, 2003). When the pruning and trimming are not performed, the forest canopy protects the litter from solar incidence, enabling a more humid microclimate, stimulating the decomposition. However, in stands where a management system is conducted or even where there are natural deaths of some trees, there is a higher incidence of sunstroke on the litter and soil, thereby changing the abiotic conditions, which influence on the decomposition process.

\subsection{Feeding activity of soil fauna}

The exposure period of 30 days proved to be efficient to get high decomposition rates of the bait lamina on the litter layer. The highest percentages of baits consumption were observed in summer (98.18\%), followed by autumn (81.08\%), while a reduced activity was observed in the spring (62.93\%) and winter (73.09\%). Statistical differences were observed between summer, spring, and winter. The results are shown in Figure 4.

Concerning bait lamina consumption, results indicated the higher feeding activity of litter organisms in summer, which corresponds to the warmer season combined with high humidity, as usual in this biome (Atlantic Forest/Mixed Ombrophilous Forest) and confirmed by the climatic data. In general, bait lamina consumption represents the feeding activity of both soil invertebrates and microorganisms (FILZEK et al., 2004), being a recognized methodology for this purpose around the world, standardized by ISO and applied in forest areas (e.g., KLIMEK et al., 2015; SANTANA et al., 2018). The results showed the positive effect of high temperature and humidity in summer promoting a higher soil fauna activity (ROZEN et al., 2010). Cold conditions or drought can reduce the fauna activity on litter surface, as a result of the migration of invertebrates to more 
deep soil layers, searching by optimal conditions, or even causing the death of some faunal groups (SILVA et al., 2013).

Figure 4 - Mean values ( \pm SD) of bait lamina consumption (\%) representing the litter organisms feeding activity within seasons, after 30 days of exposure on pine litter layer

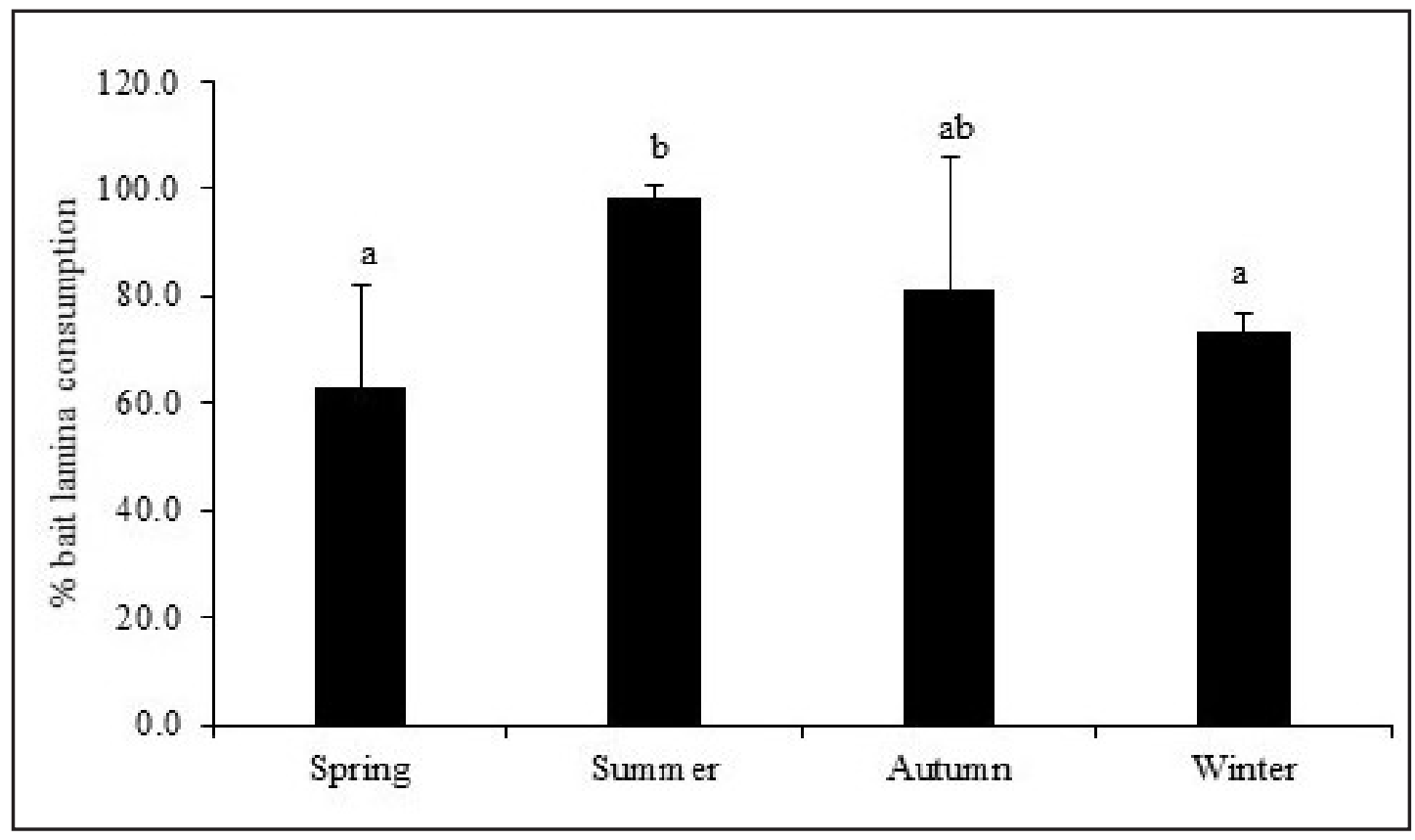

Source: Authors (2018)

In where: Averages followed by the same lowercase letters did not differ (Kruskal-Wallis, $\mathrm{p}<0.05$ ).

The bait lamina test proved effectiveness when arranged on the surface (horizontally) to determine the litter organisms feeding activity on the litter surface, as seen in Podgaiski, Silveira and Mendonça Junior (2011). In pine stands, it was necessary to use an extended time of exposure (30 d) to achieve at least $40 \%$ consumption, when compared to studies carried out in other Brazilian biomes (e.g., ROMBKE et al., 2006 in Central Amazonia). Podgaiski, Silveira and Mendonça Junior (2011) found similar results among vertically and horizontally exposed bait lamina in pasture areas in south Brazil, where the baits on soil surface showed slightly higher activity than the buried ones, probably related to high activity of surface organisms. 
Changes in abiotic conditions caused by thinning, pruning, fire, or fragmentation can modify the litter organism's activity and consequently the decomposition dynamics, e.g., increasing light entrance and consequently increasing temperature and decreasing moisture. Therefore, climatic conditions and management practices should be considered when more accurate estimative is desired involving litter lifetime or nutrient cycling in pine stands or invasions.

Understanding forest ecosystem functioning is essential to wood production as well as conservation purposes (HANDA et al., 2014). In general, the findings confirmed that forest stands of this exotic tree species do not serve as a food supply to maintain soil fauna biodiversity under Atlantic Forest biome, and, consequently, $P$. taeda stands do not promote soil fauna biodiversity and its associated functions in the soil ecosystem. Our finds bring some contribution to predicting the consequences of exotic trees stands for soil quality and biodiversity, and under climate global change.

\section{CONCLUSION}

Our results provided novel insights into pine litter decomposition dynamics and detritivore feeding activity in pine stands: (1) no significant differences in litter mass loss and decomposition rate when soil macrofauna and most of the mesofauna were excluded; (2) feeding activity of litter organisms was higher in the summer, probably stimulated by a combination of high temperature and rainfall. In general, we can conclude that soil macro and mesofauna play a low role in the pine litter decomposition, indicating that the organic material decomposition in pine stands is more related to microorganism's activity. In commercial pine stands, we can conclude that the nutrient cycling is slower than in natural areas, related to litter traits, as described in the scientific literature. Furthermore, these findings could be extrapolated to invasion areas, indicating that this exotic tree species could not serve as a food supply to maintain soil fauna biodiversity under Atlantic Forest biome, and, consequently, it could impair the soil ecosystem functioning in natural areas. 


\section{REFERENCES}

AUGUSTO, L. et al. Influences of evergreen gymnosperm and deciduous angiosperm tree species on the functioning of temperate and boreal forest. Biological Reviews of the Cambridge Philosophical Society, Cambridge, v. 2, p. 444-66, 2014.

BARBOSA, J. S. et al. Atributos físico-hídricos de um cambissolo húmico sob sistema agroflorestal no planalto catarinense. FLORAM, [s. I.], v. 24, p. 1-9, 2017.

COÛTEAUX, M. M.; ALOUI, A.; BESSON, C. K. Pinus halepensis litter decomposition in laboratory microcosms as influenced by temperature and a millipede, Glomeris marginata. Applied Soil Ecology, Amsterdam, v. 20, p. 85-96, 2002.

COYLE, D. R. et al. Soil fauna responses to natural disturbances, invasive species, and global climate change: current state of the science and a call to action. Soil Biology Biochemistry, [s. I.], v. 110, p. 116-133, 2017.

CUBBAGE, F. et al. Global timber investments, 2005 to 2017. Forest Policy Economics, [s. I.], v. 112, 102082, 2020.

DODET, M.; COLLET, C. When should exotic forest plantation tree species be considered as an invasive threat and how should we treat them? Biological Invasions, [s. I.], v. 14, p. 1765-1778, 2012.

FILZEK, P. D. et al. Metal effects on soil invertebrate feeding: measurements using the bait lamina method. Ecotoxicology, [s. I.], v. 13, p. 807-816, 2004.

FOCKINK, G. D. et al. Influence of aciculas deposition on natural regeneration in sub-woods of Pinus taeda L forest stand. Floresta, Curitiba, v. 50, n. 1, p. 1071-1080, 2020.

GAMA-RODRIGUES, A. C.; BARROS, N. F.; SANTOS, M. L. Decomposição e liberação de nutrientes do folhedo de espécies florestais nativas em plantios puros e mistos no sudeste da Bahia. Revista Brasileira de Ciência do Solo, Viçosa, MG, v. 27, p. 1021-1031, 2003.

GUO, P. P. et al. Comparison of litter decomposition of six species of coniferous and broadleaved trees in subtropical China. Chinese Journal of Applied \& Environmental Biology, [s. I.], v. 15, p. 655-659, 2009.

HANDA, I. T. et al. Consequences of biodiversity loss for litter decomposition across biomes. Nature, [s. I.], v. 509, p. 218-221, 2014.

$\mathrm{HE}$, W. et al. Understory vegetation removal reduces the incidence of non-additive mass loss during leaf litter decomposition in a subtropical Pinus massoniana plantation. Plant Soil, [s. I.], v. 446, p. 529-541, 2020.

HUANG, G.; ZHAO, H.; LI, Y. Litter decomposition in hyper-arid deserts: Photodegrations is still important. Science of the Total Environment, Amsterdam, v. 601, p. 784-792, 2017. 
INTERNATIONAL STANDARDIZATION ORGANIZATION. ISO 18311: Soil quality: method for testing effects of soil contaminants on the feeding activity of soil dwelling organisms - Baitlamina test. Geneva, 2016.

KLIMEK, B. et al. Application of the bait-lamina method to measure the feeding activity of soil fauna in temperate forests. Polish Journal of Ecology, [s. I.], v. 63, p. 414-423, 2015.

LI, X. et al. Litter mass loss and nutriente release influenced by soil fauna of Betula ermanii forest floor of the Changbai Mountains, China. Applied Soil Ecology, Amsterdam, v. 95, p. 1522, 2015a.

LI, Y. et al. Plant species rather than climate greatly alters the temporal pattern of litter chemical composition during long-term decomposition. Scientific Reports, [s. I.], v. 5, 15783, 2015 b.

LIU, W. et al. The effect of litter layer on controlling surface runoff and erosion in rubber plantations on tropical mountain slope, SW China. Catena, Amsterdam, v. 149, p. 167-175, 2017.

MCCAY, T. S.; CARDELÚS, C. L.; NEATROUR, M. A. Rate of litter decay and litter macroinvertebrates in limed and unlimed forests of the Adirondack Mountains, USA. Forest Ecology and Management, Amsterdam, v. 304, p. 254-260, 2013.

MORRISON, I. K. Decomposition and element release from confined jack pine needle litter on and in the feathermoss layer. Canadian Journal of Research, Ottawa, v. 33, p. 16-22, 2003.

NEHER, D. A.; WEICHT, T. R.; BARBERCHECK, M. E. Linking invertebrate communities to decomposition rate and nitrogen availability in pine forest soils. Applied Soil Ecology, Amsterdam, v. 54, p. 14-23, 2012.

OLSSON, B. A. et al. Predicted long-term effects of decomposition of leaf litter from Pinus taeda, Eucalyptus cloeziana and deciduous miombo trees on soil carbon stocks. Global Ecology and Conservation, [s. I.], v. 17, e00587, 2019.

ORTIZ, D. et al. Soil ecosystem changes after five decades in old-field pine forestry (Pinus elliottii Engelm) at Brazilian Atlantic forest. Journal of Forestry Research, [s. I.], 2021. In Press.

PODGAISKI, L. R.; SILVEIRA, F. S.; MENDONÇA JUNIOR, M. S. Avaliação da atividade alimentar dos invertebrados de solo em campos do Sul do Brasil - Bait-lamina Test. EntomoBrasilis, [s. 1.], v. 3, p. 108-113, 2011.

PURAHONG, W. et al. Influence of different forest system management practices on leaf litter decomposition rates, nutrient dynamics and the activity of ligninolytic enzymes: a case study from central European forest. Plos One, [s. I.], v. 9, p. 1-11, 2014.

R CORE TEAM. A Language and Environment for Statistical. Vienna: Computing R Foundation for Statistical Computing, 2018. Available from: https://wwwR-projectorg/. Access in: 11 abr. 2021. 
REZENDE, C. et al. Litter deposition and disappearance in Brachiaria pastures in the Atlantic forest region of the South of Bahia, Brazil. Nutrient Cycling in Agroecosystems, Dordrecht, v. 54, p. 99-112, 1999.

RÖMBKE, J. et al. Feeding activities of soil organisms at four different forest sites in central amazonia using the bait lamina method. Journal of Tropical Ecology, Cambridge, v. 22, p. 313-320, 2006.

ROZEN, A. et al. Soil faunal activity as measured by the bait-lamina test um monocultures of 14 tree species in the siemianice common-garden experiment. Poland Applied Soil Ecology, [s. I.], v. 45, p. 160-167, 2010.

SALAH, Y. M. S.; SCHOLES, M. C. Effect of temperature and litter quality on decomposition rate of Pinus patula needle litter. Procedia Environmental Sciences, [s. I.], v. 6, p. 180-193, 2011.

SANTANA, N. et al. Soil biological, chemical, and physical properties after a wildfire event in a eucalyptus forest in the pampa biome. Revista Brasileira de Ciência do Solo, Viçosa, MG, v. 42, e0170199, 2018.

SILVA, C. F. et al. Fauna edáfica em área periodicamente inundável na restinga da Marambaia, RJ. Revista Brasileira de Ciência do Solo, Viçosa, MG, v. 37, p. 587-595, 2013.

THOMAS, R. J.; ASAKAWA, N. M. Decomposition of leaf litter from tropical forage grasses and legumes. Soil Biology Biochemistry, [s. I.], v. 25, p. 1352-1361, 1993.

YANG, X.; CHEN, J. Plant litter quality influences the contribution of soil fauna to litter decomposition in humid tropical forests, southwestern China. Soil Biology Biochemistry, [s. l.], v. 41, p. 910-918, 2009.

ZHANG. J. et al. Litter decomposition and the degradation of recalcitrant components in Pinus massoniana plantations with various canopy densities. Journal of Forestry Research, [s. I.], v. 30, p. 1395-1405, 2019.

\section{Authorship Contribution}

\section{1 - Tatiani Maria Pech}

Forest Engineer, M.Sc.

https://orcid.org/0000-0002-5304-3202•tatianimariapech@gmail.com

Contribution: Conceptualization, Investigation, Methodology, Data curation, Formal Analysis, Writing - original draft, Writing - review \& editing 


\section{2 - Guilherme Diego Fockink}

Forest Engineer, M.Sc.

https://orcid.org/0000-0003-0949-1398•guilhermefockink@gmail.com

Contribution: Investigation, Data curation, Formal Analysis, Writing - original draft, Writing - review \& editing

\section{3 - Alexandre Siminski}

Agronomist, Dr., Professor

https://orcid.org/0000-0001-6141-6040•alexandre.siminski@ufsc.br

Contribution: Conceptualization, Project administration, Writing - review \& editing

\section{4 - Júlia Carina Niemeyer}

Biologist, Dr., Professor

https://orcid.org/0000-0001-6606-0338•julia.carina@ufsc.br

Contribution: Conceptualization, Project administration, Funding acquisition, Writing - review \& editing

\section{How to quote this article}

Pech, T. M.; Fockink, G. D.; Siminski, A.; Niemeyer, J. C. Role of soil fauna to litter decomposition in pine stands under Atlantic Forest biome. Ciência Florestal, Santa Maria, v. 31, n. 4, p. 1849-1866, 2021. DOI 10.5902/1980509852839. Available from: https://doi.org/10.5902/1980509852839. 